ADALAH : Buletin Hukum \&

Keadilan

@adalahuinjkt

buletin adalah

\title{
Jangan Jadikan Ulama 'Bak Stempel’ Pemilu
}

\author{
Ahmad Mukri Aji*
}

Tahun politik 2019 merupakan ajang pemilihan umum anggota legislatif maupun presiden dan wakil presiden. Pesta demokrasi yang tentunya melibatkan rakyat Indonesia sebagai pemilik suara. Akan tetapi kesadaran memilih dan menyalurkan aspirasi dalam pemilu kerap diabaikan oleh masyarakat. Hal ini tentunya disebabkan faktor kekecewaan dan rasa apatisme terhadap wakil rakyat dan pemimpin terdahulu. Sehingga mereka enggan berpartisipasi dalam pemilu dan beranggapan bahwa para pemimpin tidak dapat mengubah kehidupan mereka menjadi lebih baik. Anggapan mereka, bekerja lebih utama dibandingkan hanya ikut memilih pemimpin yang belum tentu amanah. Sehingga meninggalkan pekerjaan sehari untuk mengikuti pemilu dianggap mengurangi penghasilan, terlebih bagi mereka yang bekerja serabutan sebagai buruh maupun kerja harian. Bila tak bekerja sehari, maka mereka tidak mendapat penghasilan untuk menyambung hidup hari itu.

\section{Dampak}

perilaku

ini mengakibatkan terjadinya golput dalam pemilu. Hal ini senada dengan pendapat Varma yang menyatakan bahwa terjadinya golput disebabkan oleh rasa kecewa dan apatisme masyarakat yang memandang kinerja pemerintahan hasil pemilu yang kurang amanah, selain anggapan bahwa nilai-nilai

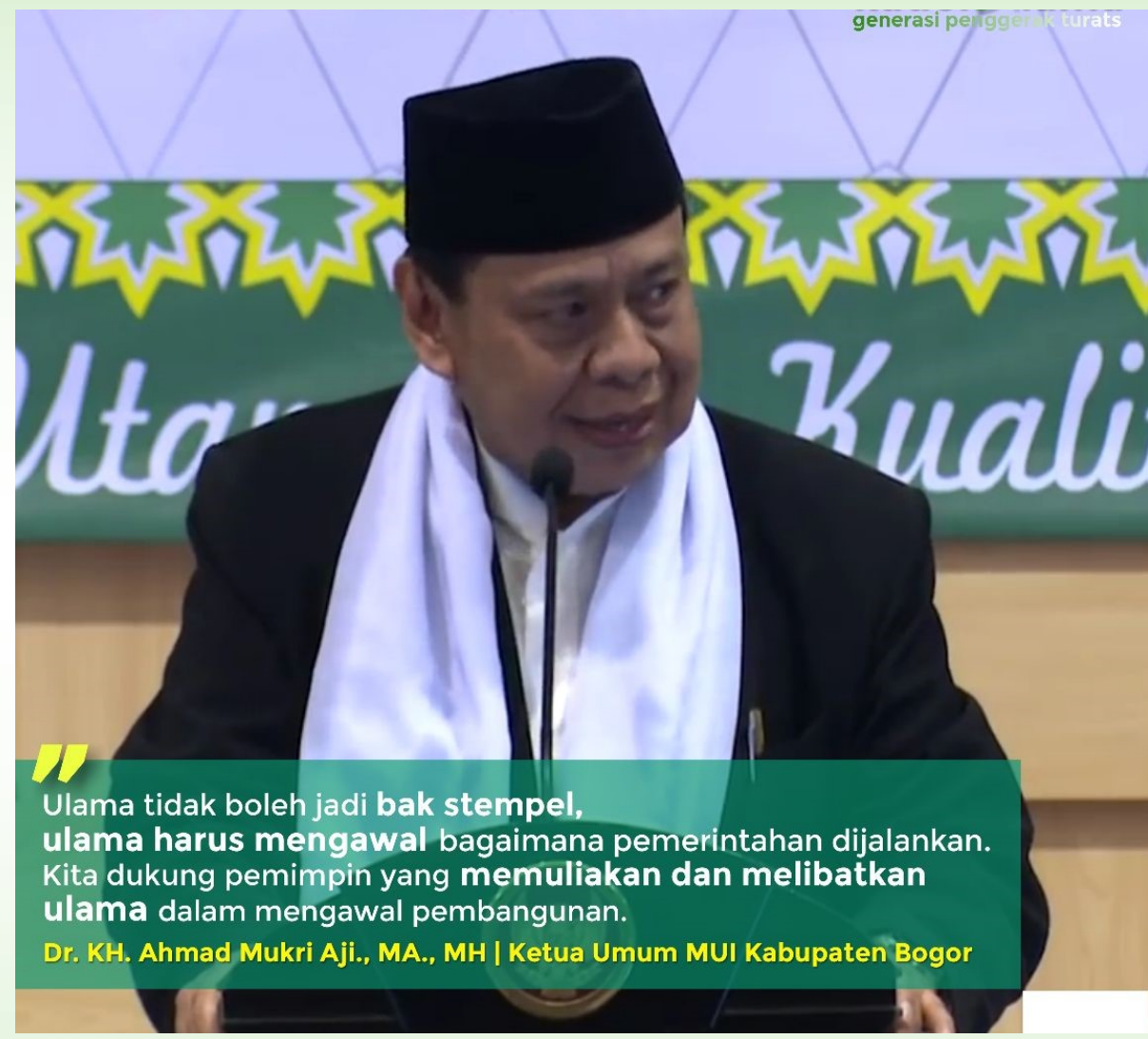

demokrasi belum mampu mensejahterakan masyarakat (Varma, 2001: 295).

Perilaku tidak ikut pemilu dengan mengedepankan tidak meninggalkan pekerjaan kerap didapatkan pada masyarakat awam khususnya di pedesaaan, daerah pelosok dan pesisir. Sehingga apabila hal ini dibiarkan akan berimbas pada keberhasilan pemilu. Meskipun berapapun besarnya kehadiran masyarakat akan tetap dianggap sah pemimpin terpilih asal telah memenuhi persyaratan perolehan suara. Hal ini sebagaimana diatur dalam pasal
159 ayat (1) Undang-Undang Nomor 42 tahun 2008 yang menyatakan bahwa suara sah apabila lebih dari $50 \%$ dari jumlah suara dalam pemilu dengan sedikitnya $20 \%$ suara di setiap provinsi yang tersebar di lebih dari setengah jumlah provinsi di Indonesia.

Ketentuan ini berlaku dan memang tidak mempengaruhi suara akibat ketidakhadiran mereka yang golput. Suara tetap dianggap sah, karena adanya kehadiran sebagian pemilik suara lainnya. Akan tetapi permasalahannya pada kepedulian masyarakat terhadap pesta 
demokrasi yang sejatinya adalah penyaluran suara rakyat. Bila partisipasi rakyat sangat rendah dalam penyaluran suara, maka dipastikan pemilu yang dihasilkan masih belum dianggap ideal dan berhasil. Disinilah diperlukan kesadaran dan partisipasi masyarakat luas di segenap lapisan termasuk masyarakat pedesaan, daerah pelosok dan pesisir.

Guna mendorong kesadaran masyarakat, maka diperlukan sosok figur yang berpengaruh dalam mendorong kesadaran mereka. Disinilah pentingnya peran ulama yang dapat mendorong dan mempengaruhi peningkatan kesadaran pemilih. Ulama, baik itu Kiai pesantren, pimpinan ormas, penceramah/ dai, para ustadz atau pun mubaligh tentunya memiliki peran besar dalam menyadarkan arti penting pemilu bagi masyarakat.

Tak heran bila kemudian banyak pasangan calon legislatif maupun eksekutif tertentu yang merangkul ulama untuk dapat merestui pencalonannya atau bahkan dijadikan mitra langsung dalam ajang kontestasi politik tertentu. Bila pada posisi minta restu pada ulama, maka aspek kultural ulama di tengah masyarakat dengan memberikan legitimasi religius atau fatwa berupa dukungan formal melalui pengajian-pengajian maupun even keagamaan tertentu. Sehingga masyarakat akan meniru dan mengikuti apa yang menjadi arahan ulama tersebut.

Akan tetapi uniknya, para elit politik kerap hanya menjadikan ulama sebatas "Bak Stempel" politik. Didatangi hanya disaat jelang pemilu, tetapi ketika hajat politik telah usai, maka ulama ditinggalkan. Nasehat dan petuah ulama tidak lagi didengar bahkan kerap diabaikan. Sehingga dampaknya, lagi-lagi masyarakat menjadi kecewa dan tidak percaya pada pemimpin yang terpilih.

Sejatinya politik sebagaimana penyataan Ramlan Surbakti merupakan interaksi antara pejabat politik (pemerintah) dan masyarakat dalam rangka proses pembuatan dan pelaksanaan keputusan yang mengikat tentang kebaikan bersama masyarakat yang tinggal dalam suatu wilayah tertentu (Surbakti, 1992:11). Jadi pasca pemilu masih harus ada sinergitas antara pemilik hajat politik dengan ulama dan masyarakat.

Peran ulama terutama Kiai memang tidak dapat dinafikan bahkan memiliki posisi sentral dan penting guna memobilisasi masyarakat untuk mendukung salah satu parpol atau paslon dalam pemilu. Apalagi ulama atau Kiai yang mempunyai pondok pesantren, maka perkataannya adalah titah yang akan diikuti masyarakat, sehingga tentunya akan meningkatkan kesadaran masyarakat untuk menggunakan hak pilihnya.

Figur seorang Ulama atau Kiai dalam pandangan masyarakat lebih dihormati dibandingkan figur-figur pemimpin yang menjabat. Suara seorang ulama atau Kiai lebih didengar dari pada suara anggota dewan maupun pemimpin daerah. Kondisi seperti ini merupakan tabiat kultural masyarakat Indonesia yang mengedepankan ketokohan kaum beragama.

Menggunakan atau memanfaatkan figur ulama untuk memenangkan pemilu memang sah-sah saja, asal ulama yang bersangkutan dengan sadar memposisikan diri sebagai pengarah ke arah yang lebih positif atau lebih baik. Tidak boleh ada kepentingan apapun kecuali untuk kepentingan umat dan agama Sehingga sosok ulama dalam percaturan kancah politik tidak melupakan tujuan mulia yaitu mengajak masyarakat untuk sadar menggunakan hak pilihnya, yang tentunya untuk memilih pemimpin yang amanah dan selalu mementingkan kepentingan umat atau rakyat.

Oleh karena hal tersebut, calon anggota dewan atau paslon pemimpin daerah yang terpilih nantinya tidak boleh hanya sekedar menjadikan ulama sebatas 'Bak Stempel,' tetapi harus selalu bersinergi dengan ulama, memimpin masyarakat dengan berpegang teguh pada kepentingan agama dan umat. Sehingga tercapai keberkahan dan kedamaian yang dirahmati Allah Subhanahu wa Ta'ala.[]

\section{Pustaka Acuan:}

* Penulis adalah Ketua Umum MUI Kabupaten Bogor sekaligus dosen tetap bidang Hukum Islam Universitas Islam Negeri Syarif Hidayatullah Jakarta.

Varma, S.P. Teori Politik Modern, Jakarta: PT. Raja Grafindo Persada, 2001.

Surbakti, Ramlan. Memahami Ilmu Politik, Jakarta: Gramedia Widya Sarana, 1992.

'Adalah; Buletin Hukum dan Keadilan merupakan berkala ilmiah yang diterbitkan oleh Pusat Studi Konstitusi dan Legislasi Nasional (POSKO-LEGNAS), Fakultas Syariah dan Hukum UIN Syarif Hidayatullah Jakarta.

Penasehat: Prof. Dr. H. Abdul Ghani Abdullah, SH., Prof. Dr. H. A Salman Maggalatung, SH., MH. Pemimpin Redaktur: Indra Rahmatullah, Tim Redaktur: Nur Rohim Yunus, Fathuddin, Mara Sutan Rambe, Muhammad Ishar Helmi, Erwin Hikmatiar. Penyunting: Latipah, Siti Nurhalimah. Setting \& Layout: Siti Romlah 